\title{
Proadrenomedullin N-Terminal 20 Peptide (PAMP) Immunoreactivity in Vertebrate Juxtaglomerular Granular Cells Identified by Both Light and Electron Microscopy
}

\author{
J. López, N. Cuesta, A. Martínez, ${ }^{*}$ L. Montuenga,$\dagger$ and F. Cuttitta* \\ Department of Biology (Cell Biology Unit), Faculty of Sciences, Universidad Autónoma de Madrid, Madrid, Spain; \\ * Department of Cell and Cancer Biology, Division of Clinical Sciences, National Cancer Institute, National Institutes \\ of Health, Bethesda, Maryland 20892; and $\dagger$ Department of Histology and Pathology, University of Navarra, \\ Pamplona, Spain
}

Accepted August 5, 1999

The gene for adrenomedullin (AM), a multifunctional peptide hormone, is expressed in mammalian renal tissue and has been shown to stimulate renin release. The exact cell source of this peptide and its gene-related partner, proadrenomedullin N-terminal 20 peptide (PAMP), in kidney is still uncertain. In the present study we have identified PAMP-immunoreactive cells in the kidney of different mammalian species, including man, by light microscopy. In addition, these cells have been further studied in mouse kidney by both light and electron microscopic techniques. At the light microscopic level, PAMP immunolabeling is preferentially located in the subendothelial cells of the enlarged glomerular afferent arterioles, that is, in the juxtaglomerular cells. However, these cells do not show immunolabeling for AM. At the electron microscopic level, the immunostaining appears inside the renin-containing secretory granules of the juxtaglomerular cells. These results confirm the direct link between renin and the AM peptide family and provide a morphological basis for studying the potential modulatory function of AM and PAMP in the control of renin activity. In contrast, neither AM nor PAMP immunoreactivities were detected in the kidney of nonmammalian vertebrates, other than in blood vessels of particular species, providing a new phylogenetic difference in the juxtaglomerular apparatus between mammalian and nonmammalian vertebrates.

(C) 1999 Academic Press
Key Words: adrenomedullin; PAMP; juxtaglomerular cells; kidney; mammals; vertebrates

Proadrenomedullin N-terminal 20 peptide (PAMP) and adrenomedullin (AM) are recently discovered regulatory peptides, both of them generated from a larger 185-amino-acid preprohormone through consecutive enzymatic cleavage and amidation. The process culminates in the liberation of 20 (PAMP)- and 52 (AM)-amino-acid-long bioactive amidated moieties (Kitamura et al., 1993, 1998). To date, these peptides have been identified in different organs and cell types, and they also seem to perform many different physiological activities. For example, AM has been found in numerous mammalian organs, including adrenal gland, heart, lung, pancreas, and central nervous system, and also in tumors of different origins. The vasodilator activity of AM has been extensively studied. AM has also been reported to influence the secretion rate of several hormones, including catecholamine, ACTH, aldosterone, and insulin. Other AM actions include bronchodilation, neurotransmission and mitogenic activity (for a review see Martínez and Cuttitta, 1998). PAMP has received less attention but has been found to inhibit chatecolamine secretion (Katoh et al., 1995) and to have a hypotensive effect through a different pathway than AM (Shimosawa et al., 1995, 1997). 
However, in certain conditions, a hypertensive activity has also been demonstrated for PAMP (Shimosawa and Fujita, 1996).

The relationship between AM and renal function was first established by Ebara et al. (1994), who pointed out a renal vasodilatory effect resulting in diuretic activity in dogs. This peptide appears to be also closely associated to renal hypotensive activity (Ishimitsu et al., 1994; Khan et al., 1997; Hirano et al., 1998; Lai et al., 1998) and to natriuretic and diuretic effects under both pathological and normal conditions (Vari et al., 1996; Eto et al., 1996; Khan et al., 1997; Samson, 1998). Natriuretic and diuretic renal activities have also been observed for PAMP (Eto et al., 1996). In addition, AM seems to be involved in modulation of endothelial and mesangial functions (Kohno et al., 1995, 1996; Michibata et al., 1998).

In some physiological studies on renal function, the presence of AM in the kidney has been demonstrated. AM gene expression and/or AM peptide secretion by mesangial cells (Ichiki et al., 1994, 1995; Owada et al., 1995; Shimokubo et al., 1996; Michibata et al., 1998; Chini et al., 1997; Lai et al., 1998) and by renal tubule cell lines (Sato et al., 1998) has been elucidated by indirect methods. In two immunohistochemical studies, performed in paraffin sections, AM immunoreactivity was detected in glomeruli, distal tubules, and medullary collecting ducts of dog kidney (Jougasaki et al., 1995, 1997). In addition, Jensen et al. (1996, 1997) have identified by RT-PCR the presence of AM in afferent and efferent arterioles, but not in juxtaglomerular granular cells in culture. They have also confirmed the stimulation of renin release by AM, an event previously reported by Hirata et al. (1995).

A specific receptor for AM has been cloned and sequenced (Kapas et al., 1995). The mRNA for this AM receptor has been identified in human lung and in pulmonary tumors (Martínez et al., 1997) and also in endocrine pancreatic islet cells (Martínez et al., 1996). $\mathrm{AM}$ and its receptor are also expressed in different rat and mouse tissues during embryogenesis, including kidney (Montuenga et al., 1997). In addition, AM and PAMP binding sites have been found in basolateral membranes of the renal tubular system (Osajima et al., 1995; Iwasaki et al., 1996). There is now some controversy with regard to the original binding properties of this receptor (Kennedy et al., 1998), and another recep- tor system has been proposed for AM (McLatchie et al., 1998).

Despite numerous studies on the physiological activity and the presence of AM gene products and their receptors in mammalian kidney, their exact cell source is still uncertain, especially for PAMP. This consideration led us to investigate the distribution of PAMP in mammalian kidney by immunocytochemical methods at the light and electron microscopic levels and also to study the presumptive presence of PAMP in renal tissue of different vertebrate groups in order to further our understanding of the phylogenetic relationships of this peptide family with the kidney.

\section{MATERIAL AND METHODS}

Kidneys of several species, including mammals (human, cow, dog, guinea pig, rat, and mouse) and nonmammalian vertebrates, have been used in this study. The species and their sources are the following:

-Fish (teleost): Zebrafish (Danios sp.) were obtained from Carolina Science Materials (Burlington, NC).

-Amphibia: Two species were used. Neotenic salamanders (Necturus maculosus, Urodela) were obtained from Carolina Science Materials, and South African frogs (Xenopus laevis, Anura) were obtained from the Animal Department, Centro de Biología Molecular, Universidad Autónoma de Madrid (CBM-UAM), Spain.

-Reptiles: Two species belonging to the Order Squamata were used for this study. The iguanians (Anolis sagrei) were obtained from CBM-UAM, and the geckos (Gecko gecko) from Carolina Science Materials.

-Birds: Domestic chickens (Gallus gallus domesticus, Warren strain, Neognata) were purchased at Avicola Grau Co. (Madrid, Spain).

- Cow, dog, guinea pig, and rat paraffin-embedded renal tissue was provided by Dr. Ted Elsasser (U.S. Department of Agriculture, Agriculture Research Service, Beltsville, MD).

-Human renal tissue sections containing no personal references were generously provided by Dr. C. Muro-Cacho (H. Lee Moffit Cancer Center, Tampa, FL).

-Mice: Five 3-month-old mice, of the NSA CF1 strain, weighing approximately $35 \mathrm{~g}$, were used (CBMUAM, protocol 28079-19A).

The animals were anesthetized with chloroform and 
their kidneys were removed and flooded with fixative. Pieces from all species were processed for light microscopic study. Small pieces of mouse kidney were also processed for electron microscopy. All procedures were approved by the Ethics and Animal Care Committee of the Universidad Autónoma de Madrid.

\section{Western Blotting}

Small pieces of mouse, guinea-pig, gecko, and Anolis kidneys were immersed in cold $2 \times$ tricine sample buffer (with 8\% SDS, Novex, San Diego, CA) containing $1 \mathrm{mM}$ final concentration of each of the following protease inhibitors: pefablock (Centerchem Inc., Stanford, CT) and bestatin and phosphoramidon (Sigma Chemical Co., St. Louis, MO). The tissue was then homogenized, sonicated, and clarified by ultracentrifugation, and the final protein concentration determined (BCA kit, Biorad Labs, Richmond, CA). Protein extracts were diluted to an approximate protein concentration of $1 \mu \mathrm{g} / \mu \mathrm{l}$, heated to $95^{\circ} \mathrm{C}$ for $3 \mathrm{~min}$, and loaded into the sample well. Protein extracts were electrophoretically separated on a gradient $10-20 \%$ tricine SDSPAGE gel (Novex) and run at $100 \mathrm{~V}$ for $2 \mathrm{~h}$ under reducing ( $5 \% \quad \beta$-mercaptoethanol) conditions. Synthetic AM (0.5 ng) or $5 \mathrm{ng}$ of PAMP were added to a separate well as a positive control. Transfer blotting was accomplished in the same apparatus equipped with a titanium plate electrode and transferred to a polyvinyldifluoride membrane (PVDF, Immobilon, Millipore) at $30 \mathrm{~V}$ for $3 \mathrm{~h}$. The membrane was blocked overnight in 1\% BSA-PBS and incubated for $1 \mathrm{~h}$ in 1:1000 dilution of rabbit anti-AM or anti-PAMP. The membrane was further exposed to biotinylated goat anti-rabbit immunoglobulins (Dakoppats, Glostrup, Denmark) (1:200) for another hour and then to avidinbiotinylated peroxidase complex (Dakoppats) (1:500) for an additional hour. Peroxidase activity was revealed with the ECL + Plus chemiluminiscence kit (Amersham, Arlington Heights, IL) following manufacturer's instructions. Specificity controls consisted of duplicate membranes incubated in antigen-preabsorbed $(10 \mathrm{nmol} / \mathrm{ml})$ antiserum.

\section{Paraffin Embedding (Light Microscopy)}

Kidney fragments were fixed in Bouin's fluid (Sigma) for $24 \mathrm{~h}$ and transferred to $70 \%$ ethanol. All the pieces were dehydrated and embedded in paraffin. Some sections were stained with hematoxylin-eosin to assess the general histology. In addition, the avidinbiotin complex (ABC) immunocytochemical technique (Hsu et al., 1981) was carried out to determine particular immunoreactivities (see below).

\section{Resin Embedding (Light and Electron Microscopy)}

Small pieces $\left(1 \mathrm{~mm}^{3}\right)$ of four mouse kidneys were fixed in $0.1 \%$ glutaraldehyde plus $4 \%$ paraformaldehyde in $0.1 \mathrm{M}$ cacodylate buffer, $\mathrm{pH} 7.2$, at $4^{\circ} \mathrm{C}$ for $2-3$ $\mathrm{h}$; then they were dehydrated through an ethanol series, cleared in propylene oxide, and embedded in an epoxy resin (TAAB-812; TAAB Lab, England) as previously reported (Martínez et al., 1996).

Semithin ( $1 \mu \mathrm{m}$-thick) sections were transferred onto glass slides and the plastic entirely removed with aged saturated sodium hydroxide in ethanol (Lane and Europa, 1965). Some deplasticized sections were stained with borated methylene blue, while others were subjected to the $\mathrm{ABC}$ technique.

For the ultrastructural investigation, suitable ultrathin sections were double stained with uranyl acetate and lead hydroxide and examined with a JEOL-1010 electron microscope. The single immunogold (IGS) staining technique (Larsson, 1988) was applied.

\section{Immunocytochemistry}

Paraffin sections were treated according to the ABC technique using as primary antisera previously characterized antibodies against P072, a fragment of AM (optimal dilution 1:1000) (Martínez et al., 1995), and against P070, a fragment of PAMP (optimal dilution 1:600) (Montuenga et al., 1997).

Background blocking was performed with normal swine serum (Dakoppats) (1:20) prior to incubation with the specific antiserum. Incubation with the primary antibodies was carried out for $16-20 \mathrm{~h}$ at $4^{\circ} \mathrm{C}$ in a moist chamber. After rinsing in Tris-buffered saline (TBS), the sections were incubated in biotinylated swine anti-rabbit immunoglobulins (Dakoppats) (1: 200) for $30 \mathrm{~min}$ at room temperature. Following a second rinse in TBS, the sections were exposed to avidin-biotinylated peroxidase complex (1:100) (Dakoppats) for $30 \mathrm{~min}$, and after a final rinse, the immunoreacted sections were visualized with diamino- 
benzidine (50 mg/100 ml; Sigma) and $\mathrm{H}_{2} \mathrm{O}_{2}(20 \mu \mathrm{l} / 100$ $\mathrm{ml})$. Developing time was $0.5-2 \mathrm{~min}$. Some sections were lightly counterstained with Harris's hematoxylin.

After deplasticization, the semithin epoxy-embedded sections were rinsed in absolute ethanol, rehydrated through a graded ethanol series, and washed twice in 0.1 M TBS, pH 7.4. Then, the ABC technique was applied with small modifications to the above method. The changes consisted in increasing the incubation time for the primary antiserum to $42-48 \mathrm{~h}$, and for the secondary antisera and the $\mathrm{ABC}$ complex up to $1 \mathrm{~h}$. Consecutive serial sections stained with different antibodies were used to study the coexistence of different peptides in the same cells.

The single immunogold staining (IGS) method was performed as follows: thin sections $(60-80 \mathrm{~nm})$ placed in nickel grids were incubated in $3 \% \mathrm{H}_{2} \mathrm{O}_{2}$ for 5 min at room temperature, followed by three washes in bidistilled water. Then, the sections were exposed to normal goat serum (NG-1, University of Navarra) (1:30) in TBS for $20 \mathrm{~min}$, followed by incubation overnight at $4^{\circ} \mathrm{C}$ with the primary antisera, diluted in $0.1 \%$ BSA-TBS. Subsequent steps, all at room temperature, included rinses in 1\% BSA-TBS and $0.5 \%$ Tween-20, incubation with goat anti-rabbit IgG-colloidal gold particles (20 $\mathrm{nm}$ in diameter) (E-Y Labs Inc., San Mateo, CA) for 45 min, rinses with $1 \%$ BSA-TBS and $0.5 \%$ Tween-20, and bidistilled water. Grids were stained for $15 \mathrm{~min}$ in $5 \%$ aqueous uranyl acetate and for $7 \mathrm{~min}$ in lead hydroxide.

\section{Controls}

Immunocytochemical controls included: (a) Replacement of the primary antiserum by nonimmune rabbit serum in the incubation medium; (b) omission of the first layer; (c) positive controls with mammalian tissues known to be immunoreactive for each antiserum; (d) preabsorption of the antibody with an excess of the corresponding antigen (1-10 nmol per each milliliter of diluted antiserum) for $18 \mathrm{~h}$ at $4^{\circ} \mathrm{C}$ prior to the immunocytochemical labeling in both liquid and solid phases; and (e) staining using $\mathrm{DAB} / \mathrm{H}_{2} \mathrm{O}_{2}$ substrate alone.

For the preabsorption control purposes we used the initial immunogens, P072 (a peptide fragment of AM) and P070 (a peptide fragment of PAMP), to block specific binding. In addition, we used synthetic CGRP and amylin (Peninsula, Mountain View, CA) to ascertain that no cross-reaction among these related peptides occurred.

\section{RESULTS}

Western blotting of mammalian kidney extracts (Fig. 1) revealed the presence of both the precursor molecule (about $17 \mathrm{kDa}$ ) and the processed peptides (3 $\mathrm{kDa}$ for PAMP and $6 \mathrm{kDa}$ for AM). The precursor band was usually seen as a doublet which coincides with previous reports that interpret them as the preprohormone (185 amino acids) and an intermediate (the lower band) (Martínez et al., 1995, Montuenga et al., 1997, 1998). In the extracts from the nonmammalian species (gecko and Anolis) the precursor was also seen, albeit with slightly different sizes, but the processed peptides were not detectable. With the antibody against AM, additional higher bands were seen in both gecko and Anolis kidneys (Fig. 1). No immunoreactive bands were evident by Western blotting using antibodies preabsorbed with the synthetic P072 and P070 peptides, therefore demonstrating the specificity of the analysis (results not shown).

The immunocytochemical study carried out in paraffin sections of renal tissue from different mammalian and nonmammalian species provided new information on the distribution of PAMP. PAMP immunoreactive cells were detected only in the renal tissue of mammalian species (Figs. 2A-2F), while the nonmammalian species did not stain at all (Figs. 2G and $\mathrm{H}$ ). The only exception was the strong PAMP positivity found in the endothelial cells of the gecko kidney (Fig. 2H). In mammals, the immunolabeled cells are located in the afferent arteriole walls (arrows in Fig. 2) and the absorption controls confirmed the specificity of the immunoreaction. In addition, AM and PAMP immunoreactivity was also found in proximal convoluted tubules (Fig. 2E) and collecting ducts of some species, in agreement with previous observations (Jougasaki et al., 1995, 1997).

In paraffin sections of mouse kidney labeled with antiPAMP, some stained cells appeared in the wall of afferent glomerular arterioles close to the corresponding glomerulus. However, these cells were not positive for AM. To clearly identify these PAMP-positive cells, 


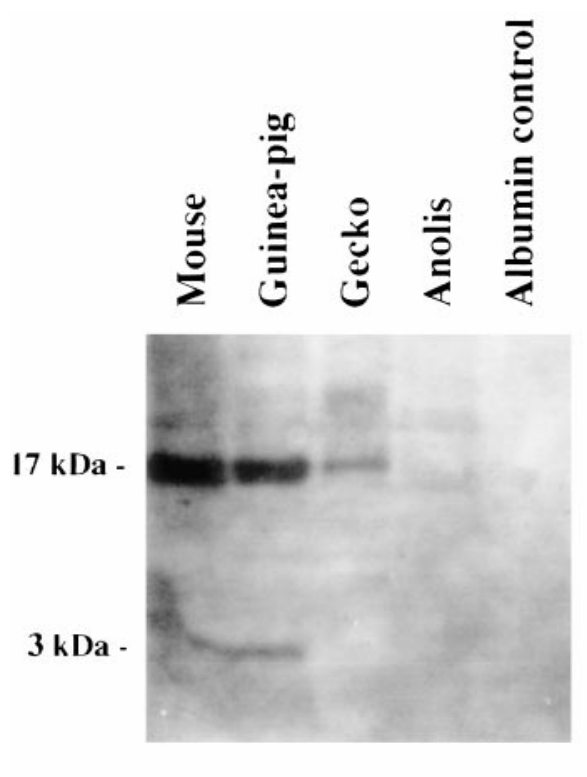

$\alpha$ PAMP

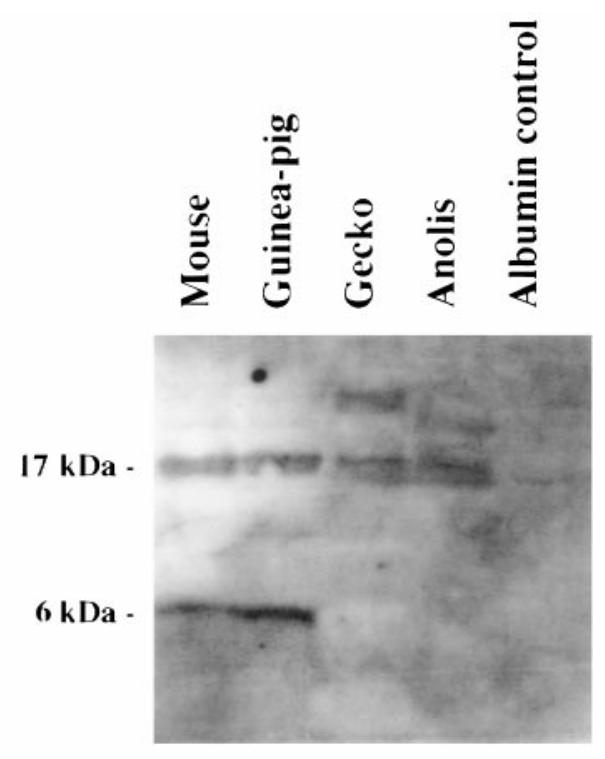

$\alpha \mathbf{A M}$

FIG. 1. Western blot analyses in extracts of kidneys from different species as detected with antibodies against PAMP (left) and AM (right). The antibodies detected a doublet of about $17 \mathrm{kDa}$ that represents the precursor molecule and bands for the fully processed, biologically active peptides, PAMP (3 kDa) and AM (6 kDa).

we performed a study in semithin sections of this species.

The PAMP immunoreactive cells observed in semithin sections showed a location and distribution consistent with that found in paraffin-embedded tissue. These cells were located under the endothelial cells of afferent arterioles, therefore identifying them as juxtaglomerular cells (Fig. 3). In addition, the immunolabeling appeared only in the cytoplasm and showed a granular pattern. The specificity of the immunoreaction was confirmed in serial sections where the staining was completely abolished after preabsorption with the antigen (Fig. 3C). Moreover, absorption controls with other structurally related peptides such as amylin and CGRP did not interfere with the labeling (Fig. 3B). In confirmation of the paraffin results, these cells were not labeled by the AM antiserum (Fig. 3D).

In a further step in unequivocally characterizing the PAMP immunoreactive cells we identified them at the electron microscopic level (Fig. 4). The immunogold technique labeled the abundant cytoplasmic secretory granules, which present moderately dense contents (Fig. 4B). All the secretory granules of the juxtaglomerular cells were labeled, although with a different density of gold particles. No immunoreaction to the AM antiserum was obtained.

\section{DISCUSSION}

In the present study we demonstrate the presence of a PAMP-like molecule in the juxtaglomerular cells of mammalian kidney using a variety of immunodetection techniques.

The titter and selective binding capabilities of the PAMP and AM antisera used in this study have been previously characterized by solid phase RIA, Western blotting, and many immunohistochemical applications. The antisera used here showed negligible crossreactivity with many other related peptides. In addition, the positive bands observed in Western blots were eliminated following antigen preabsorption of the antisera, confirming further the specificity of detection (Martínez et al., 1995). In our study, the specificity of the immunolabeling reaction was checked by preabsorption of the antibody with the corresponding antigen, which abolished the staining in all cases. An 

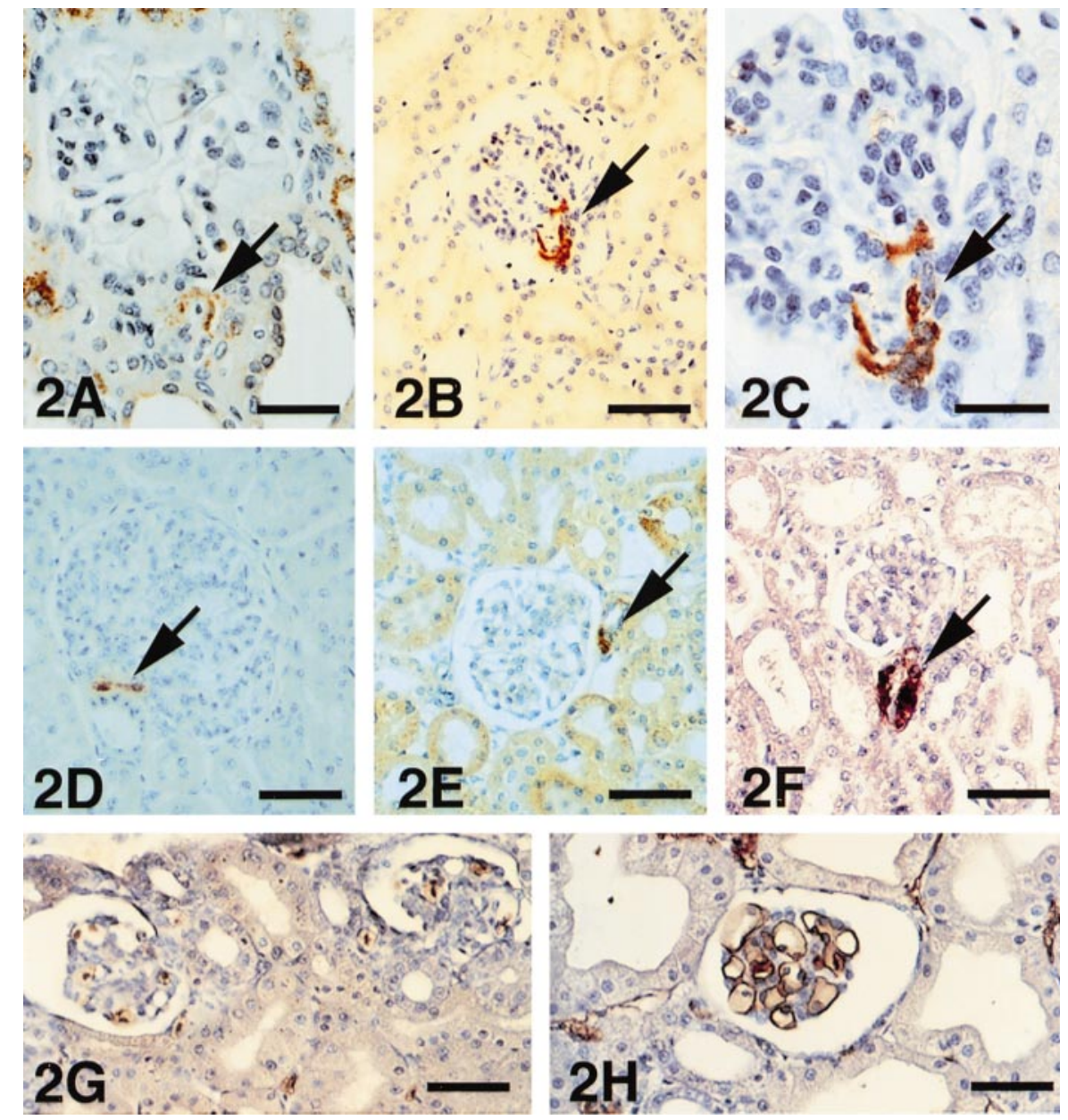

FIG. 2. PAMP immunoreactivity in the kidney of different vertebrates. (A) Human glomerulus showing positive juxtaglomerular cells (arrow). (B) Dog kidney. (C) Higher magnification of B. (D) Bovine kidney. (E) Guinea pig renal cortex. (F) Rat kidney. (G) Anolis kidney was totally negative. (H) Gecko renal tissue showing an intense PAMP staining in endothelial cells. Arrows point to positive cells in the juxtaglomerular complex. Some cells with brown color in the Anolis kidney $(\mathrm{G})$ correspond to nucleated erythrocytes and possibly represent uncomplete blocking of intrinsic peroxidase activity. A, B, D-H, original magnification $\times 450$; bar, $20 \mu \mathrm{m}$. C, original magnification, $\times 1070$; bar, $10 \mu \mathrm{m}$.

additional control of specificity was carried out by preabsorption of the antisera with amylin and CGRP, peptides structurally related to AM (Kitamura et al., 1998). In both cases, the intensity and location of the immunostaining remained unchanged, confirming the specificity of our immunolabeling procedure.

Western blot analysis showed the expression in mammalian kidneys of the precursor molecule for both AM and PAMP. In addition, fully processed PAMP and AM molecules were also detected. On the other hand, the nonmammalian kidney extracts did not show the processed peptides, although there were bands with similar sizes to the mammalian precursor molecules. This fact may indicate differences in the genetic structure and/or processing mechanism between both phylogenetic groups. In agreement with our results, Jensen et al. $(1996,1997)$ have described the expression of the AM-PAMP gene in the juxtaglomerular apparatus by RT-PCR.

By immunocytochemistry, we have shown the presence of PAMP immunoreactive cells in the kidney of several mammalian species. The immunostaining has always been found in the juxtaglomerular cells of afferent arterioles, and the electron microscopic immunolabeling has allowed the identification of a PAMP immunoreactive peptide inside the secretory granules 

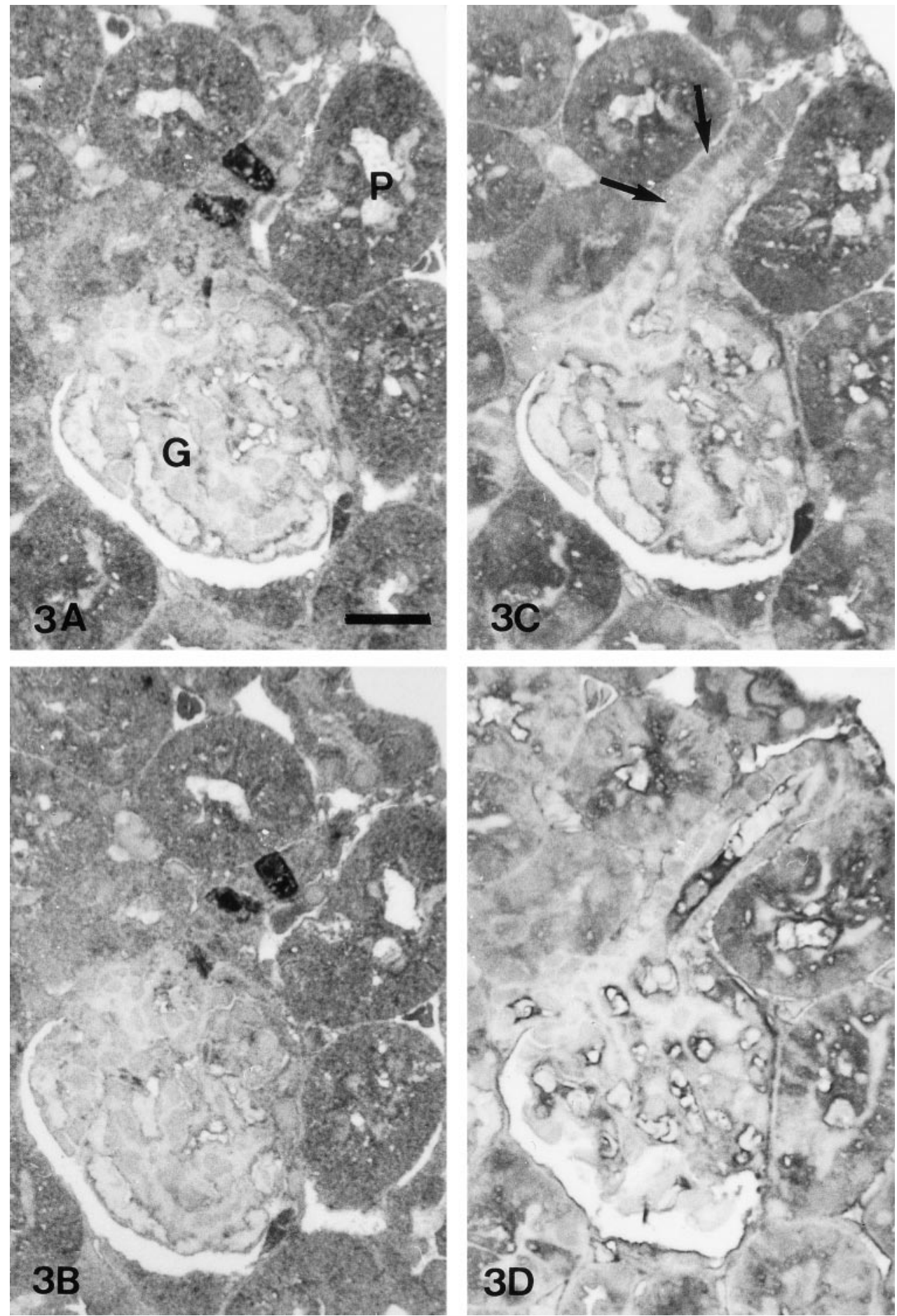

FIG. 3. Semithin serial sections of mouse kidney showing an afferent arteriole ending in the renal corpuscle, stained with anti-PAMP (A), anti-PAMP preabsorbed with amylin (B), anti-PAMP preabsorbed with its own antigen (C), and anti-AM (D). The arrows point out the same juxtaglomerular cells in the arteriolar wall labeled in A and C. G, glomerulus; P, proximal convoluted tubule. Original magnification, $\times 600$; bar, $20 \mu \mathrm{m}$. 

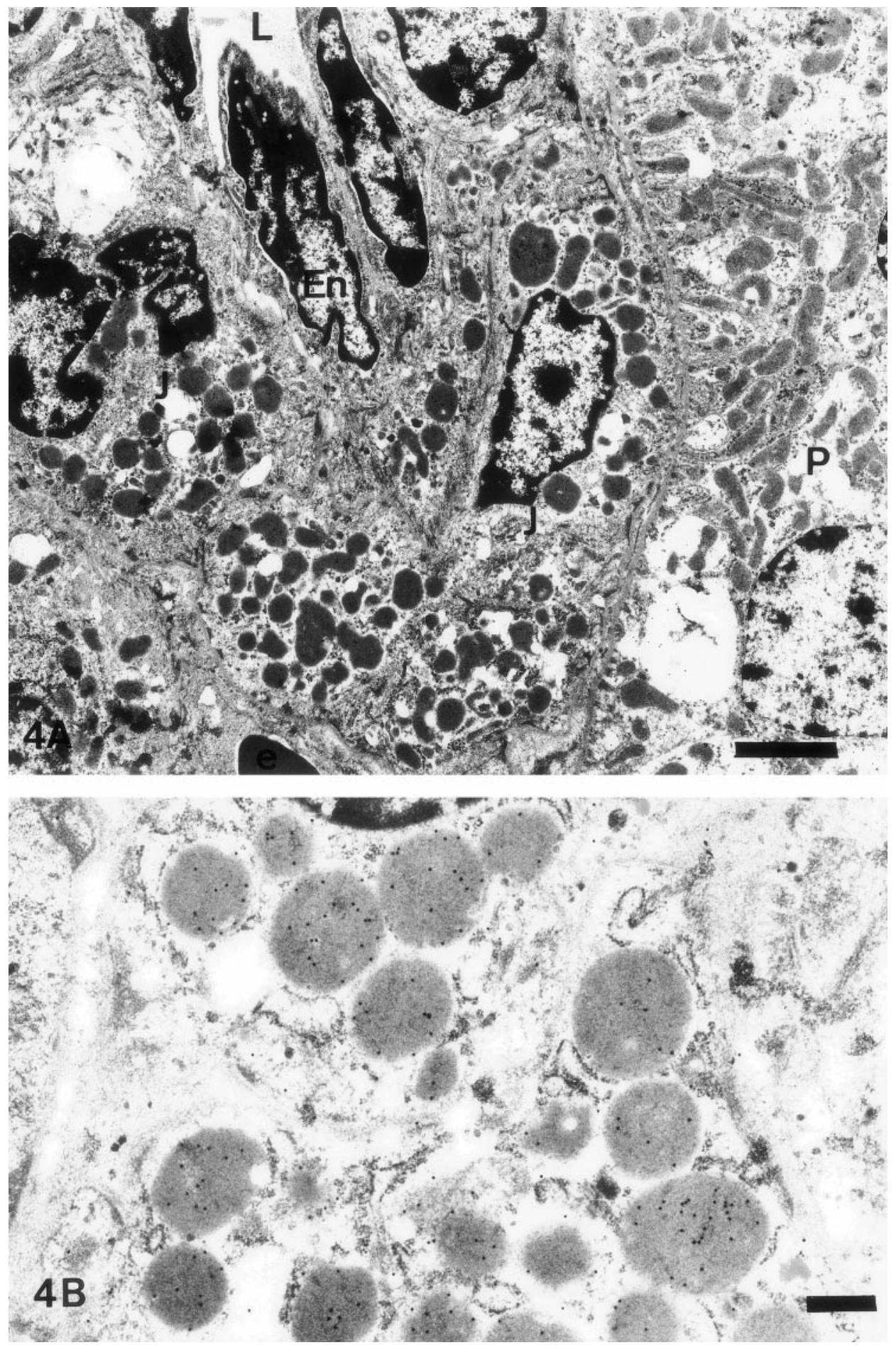

FIG. 4. (A) Electron micrograph of an afferent arteriole in the mouse kidney. The secretory granular contents of the juxtaglomerular cells (J) are labeled with anti-PAMP bound to 20-nm gold particles. L, lumen of arteriole; En, nucleus of endothelial cells; P, proximal convoluted tubule cells; e, erythrocyte inside a blood capillary. $\times 6900 ;$ bar, $2 \mu \mathrm{m}$. (B) Detail of the secretory granules. Original magnification, $\times 18,400 ; \mathrm{bar}, 0.5 \mu \mathrm{m}$. 
of these cells. Only in one case (gecko) have we found PAMP positivity in endothelial cells, although the lack of processed peptide in the Western blot analysis of this species may indicate that our antibody is detecting just the precursor molecule in this particular case. The presence of positive endothelial cells for PAMP in the gecko kidney contrasts with all other species where no immunoreactivity was found in the blood vessels. Expression of the AM-PAMP gene in endothelial cells can be modulated by many factors including interleukin 1 , tumor necrosis factors $\alpha$ and $\beta$, lipopolysaccharide, steroid hormones (Minamino et al., 1998), and glucose (Hayashi et al., 1999). It should be very interesting to find out whether differential expression of these factors may be the cause for this uncommon immunoreactive pattern.

An intriguing question to consider is why the juxtaglomerular cells do not stain for AM when they are labeled for PAMP, since both molecules are codified by the same gene. This separate expression of AM and PAMP has been previously reported in the pituitary (Montuenga et al., 1998) and in the prostate (Jiménez et al., 1999). In those cases, the authors suggested that this may be due to specific posttranslational processing or to alternative splicing of the common mRNA. This may well be the case also with the juxtaglomerular cells of the mammalian kidney but, evidently, additional investigation is needed to address this interesting question.

Another interesting result in our study is the absence of AM and PAMP immunoreactivities in nonmammalian vertebrate kidneys, with the exception of the blood vessels in the gecko. Two considerations could be made. On the one hand, this lack of immunoreactivity cannot be attributed to the antisera or the immunocytochemical techniques used, since in a previous study, performed with the same antisera, techniques, and material belonging to the same specimens, immunoreactive cells for both antibodies were found in the pancreas (López et al., 1999; and unpublished observations). Second, although the juxtaglomerular cells are present in almost all the vertebrate groups (except in most elasmobranch fishes) and the distribution of renin contents present a similar pattern, the tinctorial characteristics of the secretory granules when exposed to such techniques as iron-hematoxylin, PAS-Alcian blue, and silver impregnation, are different between mammals and nonmammals (Sokoabe and Ogawa, 1974). The juxtaglomerular apparatus are classified into two main types: those in mammals having juxtaglomerular cells, a macula densa, and extraglomerular mesangial cells and those found in reptiles, amphibians, teleosts, and holocephalians which have only juxtaglomerular cells. The avian juxtaglomerular apparatus is intermediate between those of mammals and those of lower vertebrates, having a transitional macula densa but no extraglomerular mesangial cells (Sokoabe and Ogawa, 1974; Dantzler, 1989). Consequently, the presence of PAMP immunoreactivity only in the mammalian juxtaglomerular cells could be interpreted as a new phylogenetic difference between mammalian and nonmammalian vertebrate groups as it relates to the kidney physiology.

When considering the potential functional role that PAMP plays in renal physiology, a very interesting fact derived from our observations is the colocalization of renin and PAMP immunoreactivity, which suggests the cosecretion of both peptides. The presence of renin inside the secretory granules has not been directly demonstrated in this study, but is implied by the ultrastructural characteristics of juxtaglomerular cells (Sokoabe and Ogawa, 1974; Hackental et al., 1990; Rasch et al., 1998). To date, few PAMP physiological activities have been identified. However, the cosecretion of renin and PAMP suggests a direct involvement of PAMP in the renin-angiotensin system. Considering the hypotensive, natriuretic, and diuretic renal effects of PAMP (Kitamura et al., 1994; Eto et al., 1996; Samson, 1998), this molecule may be an antagonist of the angiotensin system and thus, PAMP could be moderating the hypertensive effect of angiotensin. On the other hand, if PAMP elicits a hypertensive activity itself, as has been proposed by other authors (Shimosawa and Fujita, 1996), this peptide could be increasing the renin-angiotensin action in a synergistic manner.

An interesting aspect closely related to the reninangiotensin system is the regulation of aldosterone secretion and consequently, the modulation of renal natriuretic and diuretic functions. It is well known that angiotensin stimulates the secretion of aldosterone and therefore influences sodium and water metabolism. The natriuretic and diuretic renal activities had also been related to PAMP by Eto et al. (1996) and, recently, Andreis et al. (1998) have demonstrated that PAMP 
inhibits aldosterone secretion, while AM presents a more complex scenario in which some authors find activation of aldosterone secretion (Mazzochi et al., 1996; Kapas et al., 1998) and others claim inhibition (Yamaguchi et al., 1996). In any case, the cosecretion of renin and PAMP suggests that PAMP plays a modulatory role on the renin activity by having an antagonistic effect in natriuresis and diuresis. In addition, Jensen et al. (1996, 1997), among others, described that AM stimulates renin release in kidney; therefore, AM would be stimulating PAMP secretion from juxtaglomerular cells as well and, as a consequence, contributing to a complex AM-PAMP-renin-angiotensin-aldosterone system. Of course, there is also the possibility of renin directly regulating the expression and/or processing of the AM-PAMP gene, and the proper physiological experiments should be done to address this question.

In summary, our results confirm the direct link between renin and the AM family and also provide a new morphological basis for studying the relationship between AM, PAMP, and renin secretion and functions. In addition, the absence of AM and PAMP immunoreactivities in nonmammalian juxtaglomerular cells establishes a new phylogenetic difference between mammalian and nonmammalian vertebrates on the juxtaglomerular apparatus.

\section{ACKNOWLEDGMENTS}

We thank Prof. C. Gutiérrez, chief of Electron Microscopy Service of CBM (Centro de Biología Molecular) at the Universidad Autónoma de Madrid, for providing the electron microscope facilities; Mr. J. Palacín, chief of the Biotherium in the same institution, for providing the mice used in this study; Dr. T. Elsasser from the U.S. Department of Agriculture, Agriculture Research Service, Beltsville, $\mathrm{MD}$, for kindly providing the mammalian renal paraffin embedded material; and Dr. C. Muro-Cacho for the human sections.

\section{REFERENCES}

Andreis, P. G., Tortorella, C., Mazzocchi, G., and Nussdorfer, G. G. (1998). Proadrenomedullin N-terminal 20 peptide inhibits aldosterone secretion of human adrenocortical and Conn's adenoma cells: Comparison with adrenomedullin effect. J. Clin. Endocrinol. 83, 253-257.
Chini, E. N., Chini, C. C., Bolliger, C., Jougasaki, M., Grande, J. P., and Burnett, J. C. (1997). Cytoprotective effects of adrenomedullin in glomerular cell injury: Central role of cAMP signaling pathway. Kidney Int. 52, 917-925.

Dantzler, W. H. (1989). In "Structure and Function of the Kidney" (R. K. H. Kinne, Ed.), Vol. 1, pp. 147. Basel.

Ebara, T., Miura, K., Okumura, M., Matsuura, T., Kim, S., Yukimura, T., and Iwao, H. (1994). Effect of adrenomedullin on renal hemodynamics and functions in dogs. Eur. J. Pharmacol. 263, 69-73.

Eto, T., Washimine, H., Kato, J., Kitamura, K., and Yamamoto, Y. (1996). Adrenomedullin and proadrenomedullin N-terminal 20 peptide in impaired renal function. Kidney Int. Suppl. 55, S148S149.

Hackental, E., Paul, M., Ganten, D., and Taugner, R. (1990). Morphology, physiology and molecular biology of renin secretion. Physiol. Rev. 70, 1067-1116.

Hayashi, M., Shimosawa, T., and Fujita, T. (1999). Hyperglycemia increases vascular adrenomedullin expression. Biochem. Biophys. Res. Commun. 258, 453-456.

Hirano, S., Ishiyama, Y., Matsuo, T., Imamura, T., Sakata, J., Kitamura, K., Koiwaya, Y., and Eto, T. (1998). Decrease in circulating and urine adrenomedullin concentrations in stroke-prone spontaneously hypertensive rats. Hypertens. Res. 21, 23-28.

Hirata, Y., Hayakawa, H., Suzuki, Y., Suzuki, E., Ikenouchi, H., Kohmoto, O., Kimura, K., Kitamura, K., Eto, T., Kangawa, K. (1995). Mechanisms of adrenomedulin-induced vasodilation in rat kidney. Hypertension 25, 790-795.

Hsu, S. M., Raine, L., and Fanger, H. (1981). Use of avidin-biotinperoxidase complex $(\mathrm{ABC})$ in immunoperoxidase techniques: $\mathrm{A}$ comparison between $\mathrm{ABC}$ and unlabelled antibody (PAP) procedures. J. Histochem. Cytochem. 29, 577-580.

Ichiki, Y., Kitamura, K., Kangawa, K., Kawamoto, M., Matsuo, H., and Eto, T. (1994). Distribution and characterization of immunoreactive adrenomedullin in human tissue and plasma. FEBS Lett. $338,6-10$.

Ichiki, Y., Kitamura, K., Kangawa, K., Kawamoto, M., Matsuo, H., and Eto, T. (1995). Distribution and characterization of immunoreactive adrenomedullin in porcine tissue, and isolation of adrenomedullin (26-52) and adrenomedullin (34-52) from porcine duodenum. J. Biochem. 118, 765-770.

Ishimitsu, T., Nishikimi, T., Saito, Y., Kitamura, K., Eto, T., Kangawa, K., Matsuo, H., Omae, T., and Matsuoka, H. (1994). Plasma levels of adrenomedullin, a newly identified hypotensive peptide, in patients with hypertension and renal failure. J. Clin. Invest. 94, 2158-2161.

Iwasaki, H., Hirata, Y., Iwashina, M., Sato, K., and Marumo, F. (1996). Specific binding sites for proadrenomedullin N-terminal 20 peptide (PAMP) in the rat. Endocrinology 137, 3045-3050.

Jensen, B. L., Krämer, B. K., and Kurtz, A. (1996). Adrenomedullin is expressed in afferent arterioles and stimulates renin release and renin gene expression. Kidney Int. 50, 1810. [Abstract]

Jensen, B. L., Krämer, B. K., and Kurtz, A. (1997). Adrenomedullin stimulates renin release and renin mRNA in mouse juxtaglomerular granular cells. Hypertension 29, 1148-1155.

Jiménez, N., Calvo, A., Martínez, A., Rosell, D., Cuttitta, F., and 
Montuenga, L. M. (1999). Expression of adrenomedullin and proadrenomedullin N-terminal 20 peptide in human and rat prostate. J. Histochem. Cytochem. 47, 1167-1177.

Jougasaki, M., Wei, C. M., Aarhus, L. L., Heublein, D. M., Sandberg, S. M., and Burnett, J. C. (1995). Renal localization and actions of adrenomedullin: A natriuretic peptide. Am. J. Physiol. 268, F657F663.

Jougasaki, M., Stevens, T. L., Borgeson, D. D., Luchner, A., Redfield, M. M., and Burnett, J. C. (1997). Adrenomedullin in experimental congestive heart failure: cardiorenal activation. Am. J. Physiol. 273, R1392-R1399.

Kapas, K., Catt, K. I., and Clark, A. J. L. (1995). Cloning and expression of cDNA encoding a rat adrenomedullin receptor. J. Biol. Chem. 270, 25344-25347.

Kapas, S., Martínez, A., Cuttitta, F., and Hinson, J. P. (1998). Local production and action of adrenomedullin in the rat adrenal zona glomerulosa. J. Endocrinol. 156, 477-484.

Katoh, F., Kitamura, K., Niina, H., Yamamoto, R., Washimine, H., Kangawa, K., Yamamoto, Y., Kobayashi, H., Eto, T., and Wada, A. (1995). Proadrenomedullin N-terminal 20 peptide (PAMP), an endogenous anticholinergic peptide. Its exocytotic secretion and inhibition of catecholamine secretion in adrenal medulla. J. Neurochem. 64, 459-461.

Kennedy, S. P., Sun, D., Oleynek, J. J., Hoth, C. F., Kong, J., and Hill, R. J. (1998). Expression of the rat adrenomedullin receptor or a putative human adrenomedullin receptor does not correlate with adrenomedullin binding or functional response. Biochem. Biophys. Res. Commun. 244, 832-837.

Khan, A. I., Kato, J., Ishiyama, Y., Kitamura, K., Kangawa, K., and Eto, T. (1997). Effect of chronically infused adrenomedullin in two-kidney, one-clip hypertensive rats. Eur. J. Pharmacol. 333, 187-190.

Kitamura, K., Kangawa, K., Kawamoto, M., Ichiki, Y., Nakamura, S., Matsuo, H., and Eto, T. (1993). Adrenomedullin: A novel hypotensive peptide isolated from human pheochromocytoma. Biochem. Biophys. Res. Commun. 192, 553-560.

Kitamura, K., Kangawa, K., Ishimaya, Y., Washimine, H., Ichiki, Y., Kawamoto, M., Minamino, N., Matsuo, H., and Eto, T. (1994). Identification and hypotensive activity of proadrenomedullin N-terminal 20 peptide (PAMP). FEBS Lett. 351, 35-37.

Kitamura, K., Kangawa, K., Matsuo, H., and Eto, T. (1998). In "Adrenomedullin" (A. Martínez and F. Cuttitta, Eds.), pp. 27-39. IOS Press and Ohmsha, Amsterdam.

Kohno, M., Yokokawa, K., Yasunari, K., Kano, H., Horio, T., and Takeda, T. (1995). Stimulation of cyclic adenosine monophosphate formation by the novel vasorelaxant peptide adrenomedullin in cultured rat mesangial cells. Metabolism 44, 10-12.

Kohno, M., Yasunari, K., Yokokawa, K., Horio, T., Ikeda, M., Kano, H., Minami, M., Hanehira, T., and Yoskikawa, I. (1996). Interaction of adrenomedullin and platelet-derived growth factor on rat mesangial cell production of endothelin. Hypertension 27, 663-667.

Lai, K. N., Leung, J. C., Yeung, V. T., Lewis, L. K., and Nicholls, M. G. (1998). Gene transcription and synthesis of adrenomedullin by cultured human renal cells. Biochem. Biophys. Res. Commun. 244, 567-572.

Lane, B. P., and Europa, D. L. (1965). Differential staining of ultrathin sections of Epon embedded tissues for light microscopy. J. Histochem. Cytochem. 13, 579-582.

Larsson, L. L. (1988). "Immunocytochemistry: Theory and Practice," pp. 171-200. CRC Press, Boca Raton, FL.

López, J., Cuesta, N., Cuttitta, F., and Martínez, A. (1999). Adrenomedullin in non-mammalian vertebrate pancreas: An immunocytochemical study. Gen. Compar. Endocrinol. 115, 309-322.

Martínez, A., Cuttitta, F. (Eds.) (1998). "Adrenomedullin." IOS Press and Ohmsha, Amsterdam.

Martínez, A., Miller, M. I., Unsworth, E. J., Siegfried, J. M., and Cuttitta, F. (1995). Expression of adrenomedullin in normal human lung and in pulmonary tumors. Endocrinology 136, 4099-4105.

Martínez, A., Weaver, C., López, J., Bhathena, S. J., Elsasser, T. H., Miller, M. J., Moody, T. W., Unsworth, E. J., and Cuttitta, F. (1996). Regulation of insulin secretion and blood glucose metabolism by adrenomedullin. Endocrinology 137, 2626-2632.

Martínez, A., Miller, M. A., Catt, K. J., and Cuttitta, F. (1997). Adrenomedullin receptor expression in human lung and in pulmonary tumors. J. Histochem. Cytochem. 45, 159-164.

Mazzocchi, G., Musajo, F., Neri, G., Gottardo, G., and Nussdorfer, G. G. (1996). Adrenomedullin stimulates steroid secretion by the isolated perfused rat adrenal gland in situ: Comparison with calcitonin gene-related peptide effects. Peptides 17, 853-857.

McLatchie, L. M., Fraser, N. J., Main, M. J., Wise, A., Brown, J., Thompson, N., Solari, R., Lee, M. G., and Foord, S. M. (1998). RAMPs regulate the transport and ligand specificity of the calcitonin-receptor-like receptor. Nature 393, 333-339.

Michibata, H., Mukoyama, M., Tanaka, I., Suga, S., Nakagawa, M., Ishibashi, R., Goto, M., Akaji, K., Fujiwara, Y., Kiso, Y., and Nakao, K. (1998). Autocrine/paracrine role of adrenomedullin in cultured endothelial and mesangial cells. Kidney Int. 53, 979-985.

Minamino, N., Isumi, Y., Kangawa, K., Kitamura, K., and Matsuo, H. (1998). In "Adrenomedullin" (A. Martínez, F. Cuttitta, Eds.), pp. 79-102. IOS Press and Ohmsha, Amsterdam.

Montuenga, L. M., Martínez, A., Miller, M. J., Unsworth, E., and Cuttitta, F. (1997). Expression of adrenomedullin and its receptor during embryogenesis suggests autocrine or paracrine modes of action. Endocrinology 138, 440-451.

Montuenga, L. M., Martínez, A., Miller, M. J., Garayoa, M., Elsasser, T., and Cuttitta, F. (1998). In "Adrenomedullin" (A. Martínez, F. Cuttitta, Eds.), pp. 49-68. IOS Press and Ohmsha, Amsterdam.

Osajima, A., Mutoh, Y., Uezono, Y., Kawamura, M., Izumi, F., Takasugi, M., and Kuroiwa, A. (1995). Adrenomedullin increases cyclic AMP more potently than CGRP and amylin in rat renal tubular basolateral membranes. Life Sci. 57, 457-462.

Owada, A., Terada, Y., Sasaki, S., Marumo, F., Nonoguchi, H., and Tomita, K. (1995). Expression of adrenomedullin (AM) messenger RNA and cell cycle-independent cAMP generation by AM in cultured rat mesangial cells (MC). J. Am. Soc. Nephrol. 6, 742. [Abstract]

Rasch, R., Jensen, B. L., Nyengaard, J. R., and Skøtt (1998). Quantitative changes in rat renin secretory granules after acute and chronic stimulation of the renin system. Cell Tissue Res. 292, 563-571.

Samson, W. K. (1998). Proadrenomedullin-derived peptides. Neuroendocrinology 19, 100-127. 
Sato, K., Imai, T., Iwashina, M., Maruno, F., and Hirata, Y. (1998). Secretion of adrenomedullin by renal tubular cell lines. Nephron 78, 9-14.

Shimosawa, T., Ito, Y., Ando, K., Kitamura, K., Kangawa, K., and Fujita, T. (1995). Proadrenomedullin NH2-terminal 20 peptide, a new product of the adrenomedullin gene, inhibits norepinephrine overflow from nerve endings. J. Clin. Invest. 96, 1672-1676.

Shimosawa, T., and Fujita, T. (1996). Hypertensive effect of a newly identified peptide, proadrenomedullin N-terminal 20 peptide. Hypertension 28, 325-329.

Shimosawa, T., Fando, K., and Fujita, T. (1997). A newly identified peptide, proadrenomedullin $\mathrm{N}$-terminal 20 peptide, induces hypo- tensive action via pertussis-toxin sensitive mechanism. Hypertension 30, 1009-1014.

Shimokubo, T., Sakata, J., Kitamura, K., Kangawa, K., Matsuo, H., and Eto, T. (1996). Adrenomedullin: Changes in circulating and cardiac tissue concentration in Dahl salt-sensitive rats on a high salt diet. Clin. Exp. Hypertens. 18, 949-961.

Sokoabe, H., and Ogawa, M. (1974). Comparative studies of the juxtaglomerular apparatus. Int. Rev. Cytol. 37, 271-327.

Vari, R. C., Adkins, S. D., and Samson, W. K. (1996). Renal effects of adrenomedullin in rat. Proc. Soc. Exp. Biol. Med. 211, 178-183.

Yamaguchi, T., Baba, K., Doi, Y., Yano, K., Kitamura, K., and Eto, T. (1996). Inhibition of aldosterone production by adrenomedullin, a hypotensive peptide, in the rat. Hypertension 28, 308-314. 